\title{
Problems Faced by Muslim Converts in Sri Lanka: A Study Based on Anuradhapura District
}

\author{
Ahamed Sarjoon Razick ${ }^{1}$, Mohamed Anifa Mohamed Fowsar ${ }^{2}$ \& Ameer Rushana ${ }^{1}$ \\ ${ }^{1}$ Department of Islamic Studies, South Eastern University of Sri Lanka, Sri Lanka \\ ${ }^{2}$ Department of Political Science, South Eastern University of Sri Lanka, Sri Lanka \\ Correspondence: Ahamed Sarjoon Razick, Department of Islamic Studies, South Eastern University of Sri Lanka, \\ Sri Lanka. E-mail: sarjoonra@seu.ac.lk
}

Received: September 17, $2019 \quad$ Accepted: October 16, $2019 \quad$ Online Published: August 17, 2020
$\begin{aligned} & \text { doi:10.5539/jpl.v13n3p10 } \\ & \text { URL: https://doi.org/10.5539/jpl.v13n3p10 }\end{aligned}$

\begin{abstract}
Muslim converts are living with several problems after the conversion, and they are disowned and separated by their original relatives. Muslims by birth call Muslim converts as 'Moula-Islam' which is keeping off them as a different segment. The aim of this research is, therefore, to identify the problems faced by Muslim converts in Anuradhapura district, Sri Lanka. This is an empirical study with the applications of qualitative and quantitative data. The study adopted the questionnaire survey and in-depth interview techniques to collect primary data and randomly selected sixty-five samples out of three hundred sixty-five Muslim coverts living in Anuradhapura district. The significant finding of the study reveals that Muslim converts are facing several socioeconomic problems including the separation from family and relatives, the language problem, financial issues, the disparity in the aspect of marriage and the occurrence of divorces among married couples. The study further highlights difficulties faced by Muslim converts in terms of Islamic knowledge, learning Al-Quran, adopting Muslim cultural identity. Muslim converts are the most vulnerable people in the Muslim community, and they do not receive financial help, including Zakat from traditional Muslims. Hence, this study argues that current problems faced by Muslim converts should be addressed meaningfully and the Muslim community and voluntary organizations should take corrective measures to improve the life of Muslim converts in the Sri Lankan context.
\end{abstract}

Keywords: Anuradhapura district, Muslim converts, Islam, non-Muslims

\section{Introduction}

Religiously world society is pluralistic, and people with different cultures and religions live in every part of the world. Most of the states have accommodated religious and linguistic freedoms of religious communities. Muslims are globally living in the way of either majority or minority, and they enjoy certain religious rights and freedom in those countries. They are fighting against the imperialistic forces to defend their existence in various countries. Most of the contemporary Islamic movements want to establish a Caliphate rule to address the issues faced by the global Muslim community. Some other so-called Islamic organizations under the veil of Islam are posing disputes in various parts of the world.

The world's Muslim population is 1.82 billion (24.36\%) out of a total population of 7.6 billion. Most Muslims live in the Kingdom of Saudi Arabia (95\%), Afghanistan (98.79), Algeria (99\%), Bahrain (70.2\%), Syria (92.8\%), Iran (99\%), Iraq (97\%), Sudan (97\%) and Morocco (99.9\%). Of the total Muslim population, the Muslim minority make up 450 million, equal to $1 / 3$ of the world's total Muslim population. Out of the five, one is Muslim, and out of twelve, one is a minority, while in European countries, the Muslim population is up to 60 million. In 49 countries around the world, Muslims are the majority, and in over 150 countries, Muslims are the minority. In the Middle East, the Muslim population is $91.2 \%$, in South East Asia, it is 40\%. South Asia has 31.49\% Muslims. In Africa, the Muslim population is $29.6 \%$, the Muslim population in Europe is 6\%, and America has 0.6\% Muslims (Pew Research Center, 2017).

Sri Lanka is a country on the southeastern border of the subcontinent of India with a surface area of $65,610 \mathrm{~km}^{2}$. It is a country with a multi-ethnic society comprising Sinhalese, Tamils, Muslims, and Burghers, and has a population of $20,277,597$, with Buddhists $(70.2 \%)$ as the majority group followed by Tamil $12.6 \%$. The Muslim population is $9.7 \%$, and significant numbers of other groups are living in the country (Department of Census and 
Statistics, 2012). There are 25 administrative districts and nine provinces in Sri Lanka. Of these 25 districts, Anuradhapura is the largest district. The ancient name was Anuradhagamam. However, ancient King Pandugapaya (474 BC-376 BC) who ruled the entire island changed the name of Anuradhagamam to Anuradhapura and declared it to be the capital city of the country under his rule. Anuradhapura district has $7179 \mathrm{~km}^{2}$ area extent, and it has seven electorates, 22 divisional secretariats, and 694 G.S divisions, with a total population of 860,575. Most of them are Buddhists (90.9\%), and others are religious minorities. There are $8.0 \%$ of Muslims, $1.0 \%$ of Tamils and $1.2 \%$ of Christians (Department of Census and Statistics, 2012).

There are 114 Muslim villages in Anuradhapura district with 70,692 Muslim population (Department of Census and Statistics, 2012). Muslims and Buddhists live peacefully with mutual understanding over the centuries. Thus Buddhists could embrace Islam through the ways of day-to-day life with Muslims, places of work, livelihood activities, friendship and marriage, attitudes, behaviours and manners of Muslims. The conversion of Buddhists to Muslims in the Anuradhapura district in the five years (2012-2017) is reported as 325 in numbers. Anuradhapura town, Nachchaduwa, Nochiyagama, and Kekirawa are the villages where most Muslims live. Since Muslims live interactively with the Buddhists, some Buddhists have embraced Islam. The displaced Tamils still live with the Muslims in Ikirikollewa and Medawachiya, and they have embraced Islam in recent years.

\section{Statement of the Problem}

Islam is a religion, and it does not belong to a particular nation or ethnicity and is blessing all the people in the world. Islam does not forcibly impose the people to follow it. There are many reasons non-Muslims embraced to Islam. Reciting Al-Quran and Islamic publications persuade somebody to follow Islam. The habits, attitudes, behaviours, and approaches of fellow Muslims also influence in the conversion. Socioeconomic issues such as untouchability, cultural and economic problems faced by the followers of other religion, non-Muslims have led to embrace Islam. In the Sri Lankan context, non-Muslims also embraced Islam based on these factors. However, those who have embraced Islam face several problems both internally and externally. Especially in Anuradhapura district, Muslim converts are facing several socioeconomic issues. For example, Muslim converts' family reject or exclude them, their non-Islamic names are used to call them even after the conversion, and Muslim call them as moula-Islam in public places, and the certain people in the Muslim community treat them indifferent manner. The society discriminates their children, and some educational institutions are reluctant to teach their children, and Muslim-born children treat their children as a different segment. The traditional preachers do not prioritize the opinions and ideas of Muslim converts during $d a^{\prime} w a$ (Islamic call). If young men or young women embraced Islam, they could not marry a Muslim-born person. These are the problems with which are confronting Muslim converts in Anuradhapura district. Because of this situation, they have a feeling of isolation from the Muslim community. According to the Islamic faith, the word, 'muallafathul qulub' (those whose hearts are to be reconciled with Islam) denotes Muslim converts, and they are eligible to receive Zakat. In practice, it does not happen. In the meantime, there are no proper institutional arrangements to teach Islamic principles to Muslim converts. These issues significantly prevent non-Muslims from embracing Islam. Against this backdrop, this study attempts to examine the major problems faced by Muslim converts in Anuradhapura district of Sri Lanka over the last five years.

\section{Materials and Methods}

There are 114 villages in Anuradhapura district, and Muslims are living in most of these villages. Three hundred twenty-five (325) non-Muslims have been converted to Islam over the last five years (2013-2017). To identify the problems faced by Muslims converts in Anuradhapura District, 64 residents ( $20 \%$ of total Muslim converts) living in the respective villages were randomly selected. As this is empirical research, semi-structured interviews were conducted, and the data were statistically analyzed. The secondary data were collected from the documents obtained from the Mosques, the Quazi Court, the Mediation Board and the Zakat Committee, and informal interviews were also conducted with the officials of the above institutions. The data collected through the interviews were analyzed, and the results were categorized under different headings. The data were collected based on factors such as age, gender, level of education, types of occupation and converts' previous religions. These factors have significant influences on embracing Islam by the converts in Anuradhapura district.

\subsection{Age and Gender-based Representation and Level of Education}

Based on the age and gender of the respondents, 28 male participants (40\%) and 38 female participants (60\%) were selected to collect primary data. The number of women is higher than the number of men who took part in this survey. According to the data, those between the ages of 20 and 30 embraced Islam, accounting for $44 \%$ of the total. Those between 31 and 40 years of age are $34 \%$, and those between 41 and 50 are $6 \%$. But those over 50 years of age, accounting for $16 \%$ of the total converts, could not be identified whether they embraced Islam or Muslim-born. They are therefore seen as the original Muslims with enormous changes. Of the participants, $48 \%$ 
have received secondary education, $38 \%$ have received primary education, while $14 \%$ have received vocational qualifications.

\subsection{Types of Occupation}

Based on the occupation, most of the participants (52\%) are engaged in farming and business, and 39\% are unemployed. A few numbers of converts are engaged in daily wage labour $(3 \%)$ and agriculture $(6 \%)$. Mainly when non-Muslim traders or business people work with Muslims, they have a close relationship with them. On such occasions, non-Muslim traders observe the excellent characters of the Muslims in terms of their faith, trustworthiness, ethical conduct and sanctity. Non-Muslims attracted the habits of trading in the business activities of Muslims, such as sympathy for others and a corporation with others. Also, when non-Muslims work as labourers under Muslim business proprietors, they observe the proprietor's habits that the way they treat non-Muslims to pay salary and paying attention to their living conditions. Hence, Non-Muslims attract Islam as a way of life.

\subsection{Factors Influenced on Embracing Islam}

When looking at the factors for embracing Islam by non-Muslims, those who embraced Islam for marriage opportunities are more than half (58\%). These marriage events are caused by affection and love between couples without the consent of their parents. $20 \%$ of them are migrants who have left their home countries for employment in Muslim countries, especially the Middle East, who are attracted by Muslim culture and Islamic principles. 13\% of non-Muslims embraced Islam through their Muslim neighbours. $9 \%$ of non-Muslims embraced Islam because of connections with Muslims related to economic reasons and ethical behaviour of Muslims.

\subsection{Religions from which the Participants have Converted}

In Anuradhapura district, most of the converts belong to the Buddhism or Sinhalese ethnic community over five years. However, a significant number of people from Hindu and Christianity embraced Islam. 36 Buddhists (56\%), 20 Hindus (31\%) and 8 Christians (13\%) were selected as samples for the study. According to the observation, $1 / 3$ of the participants' habits expose the Islamic way of life. After having embraced Islam, daily habits or behaviour are like those of the Muslim-born. It's because of living closely with Muslims in an Islamic environment. Some Muslim converts changed their lifestyle according to Islamic principles. In some extent, the behaviours of the Muslim converts are far better than the activities of Muslims by birth in Anuradhapura district.

\section{Results and Discussion}

This section analyzes qualitative and quantitative data collected from interviews and questionnaires, and it discusses socioeconomic and religious problems faced by Muslim converts in Anuradhapura district under the following subtitles. According to the survey, $10 \%$ of those surveyed said that their families neglect them. In some extent, their family abandon them. $7 \%$ of respondents pointed out that disagreement between husband and wife is a major problem. A certain number of respondents showed that Muslim converts face several issues such as divorce $(2 \%)$, the disparity in marriage affairs $(10 \%)$, language difficulties $(6 \%)$, and psychological problems $(12 \%)$. The study found that $2 \%$ of respondents had a reluctance to wear Islamic clothing. The research further shows that Muslim converts have many economic and other problems too. According to the results, $5 \%$ of those surveyed said that they did not receive Zakat from Muslims. Further, it was observable that there is a lack of access to their children's education. Even they did not have adequate incomes for their daily life.

\subsection{Religious Issues}

In Anuradhapura district, Muslim converts face various religious challenges. They face difficulties in acquiring basic Islamic knowledge, learning to recite the Quran, nurturing Islamic culture to their children, adopting the Islamic way of life, exposing Islamic identity and changing their name. We can explore these crises under the following subheadings.

1) Difficulties in acquiring Islamic knowledge: The study found that $70 \%$ of the respondents did not have sufficient understanding of the principles of Islam, and many of them are not clear on how they can gain Islamic knowledge. Some Non-Muslims convert to Islam by marrying Muslim men. Some Muslim converts want to learn Islam, but they do not have enough opportunities to do so. When the husband has a lack of Islamic knowledge, he cannot impart knowledge of Islam to his converted wife. Some Muslim converts try to learn Islam on their own and practice it in their daily lives. However, there are situations where many live without adequate Islamic knowledge. $11 \%$ of those surveyed said they were facing difficulties in acquiring Islamic knowledge and performing their duties properly. There is no provision in the study area for the proper dissemination of Islamic knowledge. Although there are many mosques and charities in a particular district, they do not provide appropriate Islamic education and guidance to Muslim converts. 
According to the Islamic faith, while anybody converts to Islam, they become a true Muslim. The Muslim community must provide Islamic education and integrate them into the traditional Muslim society. But they keep Muslim converts at a distance from the community. It was observable that $75 \%$ of Muslim converts surveyed in Anuradhapura district did not have adequate basic Islamic knowledge. Some embrace Islam intending to marry Muslim men or women. Although some people accept Islam through acquiring Islamic knowledge, in practice, they do not perform their Islamic duties properly. Most people do not understand Islamic principles. The lifestyle of most Muslim converts differs from the Islamic way of life. A lack of adequate Islamic knowledge is the root cause of this disastrous situation. One respondent expressed his feeling: "We do not have opportunities to learn and understand Islam, although we are very much interested in learning Islam." However, the participants want to live in an environment that facilitates to learn Islamic principles. In such regions, mosque trustee boards make special arrangements for Muslim converts to learn Islam properly.

2) Difficulties in learning Al-Quran: 8\% of those surveyed face difficulties reciting the Quran. Learning the Quran and adapting one's life, according to Al Quran is a fundamental duty of every Muslim. It is necessary to remember at least some chapters of the Al Quran to perform daily prayers, which is one of the obligatory duties of Islam. In the same vein, reciting Al Quran is a good thing in the Islamic faith. Unfortunately, there is an uncertainty among Muslim converts on this matter. Sometimes, they are ignorant of the importance of the Al Quran. At the community level, there are no institutional arrangements that can emphasise the importance of the Holy Quran among Muslim converts. The converted women cannot learn the Quran when their Muslim husband does not have adequate knowledge to recite it. There are several challenges in learning the Quran outside the home. That is why Muslim converts face various difficulties in learning about the Holy Quran.

3) Obscurity in the principles of Islam: It was observable, a situation where Muslim converts do not accept some basic principles of Islam. Many converts, especially from Buddhism and Hinduism, are still idolatry worshipers. Some are reluctant to accept the doctrine of one God, which is the basic tenet of Islam. Some view the Prophet Muhammad as a god. In such a way, their previous religious thoughts mostly influenced them. An interviewee commented that "although I have accepted Islam, I still go to my previous worship places. In some occasions, I am engaging in the worship. In Islam, fasting is an important duty. It is a good thing to know about the hunger of the poor. However, it is a hard task for me to do every year." A significant number of Muslim converts have the same opinions. The reason for such a view is the lack of clarity about Islam. That is why the parties concerned should pay more attention to this matter. As a community, Muslims should have to feed them a clear and accurate Islamic knowledge, and every individual must understand and act on the fact since it is a social duty.

4) Bearing children according to the Islamic way of life: In Anuradhapura district, more females have converted to Islam than males. $9 \%$ of them said that they are facing difficulties in bearing their children according to the Islamic way of life. Some converts from Buddhism to Islam do not have a clear understanding of the Islamic way of life. Such people are bearing their children according to their previous religion. Although they left their former faith and converted to Islam, they did not want to give up their past culture and language. Their previous religious practices and customs continue to be influential in their day to day life. Most of the Muslim converts send their children to Sinhala language schools. The opportunity for their children to learn Islam in those schools is minimal. Thus, their children could not correctly learn Islam.

5) Difficulties in changing previous names to Muslim names: Those who accept Islam also face crises in changing their last names. $10 \%$ of those surveyed reported experiencing such problems. Sometimes the parents have changed their names, but they are not willing to change the previous names of the children. At the community level, converts are at risk of being called by their former names. As a result, some converts expressed dissatisfaction with their conversion. Still, others have a satisfactory position on conversion. During the study, it could able to observe that a converted boy had been learning in a Muslim religious school for 14 years without changing his previous name. It also causes psychological issues sometimes. The study also found that another 10-year-old boy involved in learning activities without changing his name. The practical difficulties in changing the name are an essential aspect. Although some people change their name, they face problems in obtaining a new birth certificate. Some respondents who wanted to get new birth certificates have been waiting for many years.

6) Difficulties in the expression of Muslim identity: Muslim converts face significant problems in expressing their Islamic identity. $40 \%$ of those surveyed face such crises. Some of them do not reveal Islamic identity while maintaining social relations. They also find significant differences in their dress and cultural practices. Some are reluctant to present themselves as Muslims sometimes. They believe that such an expression of Muslim identity would lead to their complete exclusion from their previous community. In terms of cultural identity, there is a gap in the relationship between traditional Muslims and Muslim converts. Sometimes traditional Muslim groups do 
not include Muslim converts into the usual social activities. Thus Muslim converts face psychological problems including depression, hatred and anger.

7) Marriage issues: Islam welcomes married life. Islam has laid down clear rules and regulations for this. Everyone who accepts Islam as their way of life should arrange their married life in how Islam directs. The marriage system that Islam shows helps in making family life better. In the view of Islam, marriage is a religious aspect. Islam holds that marriage is a tool for social development. It is essential for a man and a woman to get married in Islam. Here, Muslim converts face several crises. Several marriages between converts are taking place in opposition to Islamic practices. Many people get married without the consent of their parents. Similarly, traditional Muslim families are not interested in marrying Muslim converts. Sometimes there is a situation where Muslim converts are living alone for a long time.

8) Language issues: Language is an integral part of social life. This is the most crucial crisis faced by Muslim converts. Mother tongue of Muslims in the study area is Tamil. Although many Muslims can speak in Sinhala, they use Tamil in their daily practice. But Muslim converts from Buddhism have Sinhala as their mother tongue. They face some difficulties in maintaining community relations in the Tamil language context. Schools, such as Arabic madrasas, teach its courses in Tamil and Arabic. Some also pointed out that it affects the education of their children. It requires knowledge of the Arabic language to recite the Al Quran. Here, Muslim converts face language problems. Sometimes, the language is also a barrier for converts to maintain good relations with their new family members.

9) Humiliation issues: Some traditional Muslims disgrace Muslim converts in community affairs. $70 \%$ of those surveyed reported that they are subjected to such humiliation. Thus it was also possible to observe that sometimes there were some contradictions between traditional Muslims and Muslim converts. Muslim by birth did not invite Muslim converts to take part in Muslim events, including weddings, cultural events, festival celebrations, family functions, and other important gatherings. Many of those invited to such celebrations said that they feel isolated from the traditional Muslim community. The Muslim community has to finesse this issue. According to the Islamic faith, there is no distinction between Muslim converts and Muslims by birth. Islam looks at everyone from one perspective. In the early days of Islam, many embraced Islam from other religions. Hence, Muslim converts are a part of the Muslim community.

10) Cultural dress code: The dressing is a matter in cultural identity. However, Muslim converts' style of dress varies from the dress code of the Muslim community. Islam has given clear guidelines in the matter of dress. But Muslim converts face some difficulties in entering the Islamic dress culture. They noted that it was difficult to break free from their traditional dress code and adopt a new one. Around $30 \%$ of those surveyed have difficulty accepting the Islamic dress code. An interviewee said that "I do not have an adequate understanding of Islamic dress code. I continue to follow my usual dressing culture. So I feel that it has isolated me from the Muslim community. I find it is difficult to wear Islamic clothing." Significant number of Muslim converts, however, reported that they are wearing Islamic dress and having a comfortable feeling. However, the dress code remains a significant issue for most Muslim converts in the particular district.

11) Isolation from family: About $75 \%$ of Muslim converts are facing this problem. Family members and others in the surrounding area rarely show their usual support after they embraced Islam. $65 \%$ of the participants said that they have precisely separated from their birth families. It could observe that those who embraced Islam got married without the consent or support of their parents. Those Muslim-born helped the non-Muslims to accept Islam to get married, are having a fear that their family's reputation would be affected. Under some other circumstances, nonMuslims understood Islam as a religion, embraced it, and then passes on to their families about this change of religion. Still, their family members have angry and drove them out of the family. Some have migrated to foreign countries for employment opportunities, and have also embraced Islam, of which very few live in their villages with strong feelings. But their family members or relatives have isolated them and Muslim converts feel and empathy alone. Although they have got children, their families do not come to live together. Thus, they have lost the family support, tolerance, and mutual understanding, and the family members have made efforts to unleash anger, antagonism, and hostility towards them.

12) Contradiction among married couples: The study found that there are various conflicts between converted couples and many factors that influenced to cause friction between the husband and the wife. Minor contradictions in married life significantly affect Muslim converts. Sometimes, disputes between converted couples lead to divorce. When a husband and wife do not have a clear vision of Islam, they do not have Islamic manifestations in their life. When a husband or wife tries to perform their religious duties and enjoy rights, a conflict arises between them, because one of them (husband or wife) does not understand Islamic principles. Sometimes, the arguments 
between the husband and the wife continued to lead to violence. When Muslim converts are women, she marries a Muslim. She expects her husband could change his religious practices according to her wishes. If he does not behave in such manners, she blames her husband's habits and customs.

13) Psychological problems: Every problem that converts face causes them mental distress. Issues such as isolation from their own families, loss of support from their family and friends, acceptance of new culture, living in a new environment, aceptance of new religious practices, discrimination by the traditional Muslim community, and economic crises have created psychological crises among Muslim converts. It could observe that many Muslim converts are in a state of hopelessness. The study found that the lack of Islamic cultural awareness among Muslim converts also contributes to the psychological problems they face. Those who accept Islam are not interested in adapting themselves Islamic way of life.

\subsection{Economic Problems}

Muslims face various economic problems in Anuradhapura district. According to Islamic principles, wealthy Muslims should pay Zakat to people converts to Islam. However, in the particular district, Muslim converts did not get such help. Those who have newly joined Islam are suffering without adequate income to carry on their daily activities. We can discuss these crises under the following sub-headings.

1) Not getting Zakat: Islam pays as much attention to Zakat as it does to daily prayers. According to the Holy Quran, eight groups are eligible for receiving Zakat. Among those Muslim converts is a significant group, called Muallafathul Qulub in Arabic. Of those surveyed, $70 \%$ of respondents pointed out that they do not receive Zakat regularly. Commenting on this, one respondent said, "Although we have just converted to Islam, we have not yet received any goods or money in the name of Zakat." In some extent, mosques collect the Zakat and institutionally manage them in Anuradhapura district, but those who are new to Islam do not receive an exact share. Although these people direly need Zakat, anybody does not correctly identify their problems and not provide Zakat to them regularly.

2) Lack of adequate income: Most of the converts to Islam in Anuradhapura district are from families engaged in daily works as labourers. Sometimes they lose their regular income and livelihood when they convert to Islam. They also do not receive professional guidance from the Muslim community. Sometimes, they are hired for lower wages. Thus they are facing massive difficulties in carrying on their daily life. A Muslim husband in the family takes full responsibility for supporting a converted wife. When the husband does not have any decent income, their life goes to a terrible level. One respondent stated that "I converted to Islam through the contact with my husband. I have too much faith in Islam. But at present, my husband finds himself when he cannot do any business. Thus my family is struggling to live. My family and neighbours are not doing any help after the conversion."

3) Lack of facilities for children's education: Education plays a vital role in social development. However, Muslim converts face various crises in educating their children. Their children do not have adequate facilities to receive an education. The economic crisis they are facing has affected the education of their children. Thus the dilemmas that their children face in getting school education have changed their social relationship. This may affect the future of those children. The study identified ten families facing similar crises. It was also found that these families do not send their children to school due to their income level. There is a situation where there are no community-level organizations that can focus on this issue. An interviewee said that "we have no income to send our children to school. Although the matter was brought to the attention of the mosque Trustee Board, they did not take any appropriate action until now. As new converts to Islam, we face enormous difficulties in rebuilding ourselves socially and economically. We hoped that Muslims and our non-Muslim families would help us, but unfortunately we could not get considerable help." In this matter, the Muslim community should pay more attention. Only by providing appropriate help to those in need can enhance their standard of living and build goodwill on the Muslim community. Muslim converts also face psychological trauma as they face a series of crises since their conversion.

\section{Conclusion}

Many Muslim converts do not have explicit knowledge of Islam, even though they have the interest to learn or understand it. They had missed the opportunity, on the one hand, to learn Islam themselves, and, on the other hand, the Muslim community did not establish a teaching mechanism for Muslim converts in the particular district. Although Muslim converts embrace Islam for various reasons, they have to face several difficulties in reciting AlQuran and understanding Islamic fundamentals. In the view of most non-Muslims, non-Muslims have come forward to embrace Islam because of Muslim religious preaching and propaganda. However, it is noteworthy to mention that non-Muslims are turning to Islam for several reasons, including their own will, other than Islamic religious teaching and propaganda. 
Meanwhile, some members of Muslim-born families frequently discriminate and mistreat Muslim converts. They have to struggle to maintain the social relationship with the traditional Muslim community, and there is a lack of arrangement to address the issues faced by them. In most cases, Muslim converts' families and relatives did not accommodate them into their social life, and they cannot get the moral support of their families. They also face horrible economic vulnerabilities and catastrophes in coexisting with ordinary society. It was observable that the Muslim converts face social exclusion in the particular study area. Although these segregation activities are contrary to Islamic beliefs, it is deep-rooted in practice. Hence, the Muslim community should take communitylevel actions to improve the living standards of Muslim converts. In these regards, mosques and Muslim voluntary organizations should consider the alternative remedial measures to address the grievances of Muslim converts in Anuradhapura district.

\section{Acknowledgment}

This paper is based on the findings presented at the $5^{\text {th }}$ International Symposium - 2018 on Sustainable Development through Arabic and Islamic Studies, conducted by the Faculty of Islamic Studies and Arabic Language, South Eastern University of Sri Lanka and the draft version of the paper appeared in the particular conference proceedings. The authors of this paper contributed equally to revise and rewrite the paper incorporating new inputs and suggestions pointed out at the symposium and provided by the reviewers of the journal. The authors declare no conflict of interests publishing this article.

\section{References}

Alatas, S. F. (Ed.). (2005). Singapore covering Islam: Challenges \& opportunities for media in the global village. Singapore: Centre for Research on Islamic and Malay Affairs (RIMA).

Department of Census and Statistics-Sri Lanka. (2012). Statistical abstract of the Democratic Socialist Republic of Sri Lanka. Colombo, Sri Lanka: Department of Census and Statistics-Sri Lanka. Retrieved from http://www.statistics.gov.lk/districtstathbook.asp?district=anuradhapura

Kassim, S. B. M., Abdullah, M. S. Y., \& Baba, Z. (2013). A survey of problems faced by converts to Islam in Malaysia. Journal of Social Science and Humanities, 8(1).

Kose, A. (1994). Conversion to Islam: A study of native British Converts (PhD Thesis). London: King's College, London.

Mikail, I., Haruna, U. F., \& Owoyemi, M. R. (2016). Historical investigation to the problems and challenges of Muslims in Papua New Guinea. International Journal of Culture and History, 2(1). https://doi.org/10.18178/ijch.2016.2.1.035

Pew Research Centre. (2017). Muslims and Islam: Key findings in the U.S. and around the world. Retrieved from https://www.pewresearch.org/fact-tank/2017/08/09/muslims-and-islam-key-findings-in-the-u-s-and-aroundthe-world/

Rahman, A. A. (2015). An analysis of the challenges and prospects of convert to Islam in the Greater Accra Region (M.Phil. Thesis). Ghana: Department for the Study of Religions, University of Ghana.

Ricci, R. (2011). Islam translated: Literature, Conversion, and the Arabic Cosmopolis of South and Southeast Asia. Chicago: University of Chicago Press. https://doi.org/10.7208/chicago/9780226710907.001.0001

Sahad, M. Z., Siti Aishah Chu Abdullah, S. A. C., \& Abdullah, S. (2013). Malaysian news report on Muslim converts' issues: A study on Malaysiakini. International Journal of Humanities and Social Science, 3(13).

\section{Copyrights}

Copyright for this article is retained by the author(s), with first publication rights granted to the journal.

This is an open-access article distributed under the terms and conditions of the Creative Commons Attribution license (http://creativecommons.org/licenses/by/4.0/). 